Гордана Јовановић

\title{
СВЕТО ПИСМО КАО МОТИВ И БИБЛИЈСКА МЕСТА У „СКАЗАНИЈУ О ПИСМЕНЕХ” КОНСТАНТИНА ФИЛОЗОФА
}

Константин Филозоф или Константин Костенечки (назван тако по месту у коме је рођен $)^{1}$ провео је део свог живота у Србији, у коју је дошао између 1410. и 1413. године. Посредно се може са доста поузданости закључити да је боравио у Београду, на двору деспота Стефана Лазаревића, а највероватније и у другим духовним и културним центрима тадашње Деспотовине (нпр. у манастиру Ресави - Манасији, Деспотовој задужбини). Из родне Бугарске избегао је пред турским зулумима и прибежиште је нашао у српској земљи. Кад је Београд 1427. г. поново пао у угарске руке, Константин одлази ћесару Угљеши, господару области око Врања, Иногошта и Прешева. ${ }^{2}$ Умро је после 1439. г., али се не зна место његове смрти.

Откуд Константин баш у Деспотовини, на двору деспота Стефана? У време Константиновог доласка Деспотовина живи у релативно мирним временима. Мир са Турском је за неко време обезбеђен и деспот Стефан све чини да своју државу уреди према најбољим традицијама својих великих немањићких предака. Следи убрзани привредни развој, нарочито се развијају рударство и занатство, ${ }^{3}$ учвршћује се врховна власт, обнавља се рад „најугледније установе српске државе - државни сабори на којима су, поред владара и његове породице, били присутни патријарх, високо свештенство и властела". 4 Деспот, не само што је вешт државник и војсковођа, него је и образован човек, вичан писању, зналац језика, па се труди да и на културном пољу следи традиције својих немањићких претходника. Ктитор је многих манастира, окупља око себе учене монахе и лаике

${ }^{1}$ К. Куев - Г. Петков, Събрани съчинения на Константин Костенечки, Изоледване и текст, БАН, София, 1985, стр. 14.

${ }^{2}$ Историја српског народа, II, Београд, 1982, стр. 55.

${ }^{3}$ Нав. дело, стр. 100, 102, 105 и даље.

${ }^{4}$ Нав. дело, стр. 111. 
из Византије и Бугарске који развијају живу књижевну и преписивачку делатност. ${ }^{5}$ Један од таквих је и Константин Филозоф. Из његовог дела Сказаније о писменех (које сам превела као Повест о словима) сазнајемо да је учио код Андроника, ученика познатог патријарха Јефтимија бугарског. Како се место Костенец налази близу Бачковског манастира, у коме је боравио патријарх Јефтимије, сигурно је да је и Константин тамо био па је знања из ортографије и граматике стицао и од других Јефтимијевих ученика. ${ }^{6}$

Сказаније о писменех по своме текстолошком склопу представља својеврсну симболику: састоји се од 40 глава, а почетно слово свако главе сачињава акростих који гласи: самодржавному деспоту Стефану раб Константин (почетак 6. главе није сачуван па недостаје слово р); познато је да је словенска азбука имала 38 слова, а Константин, како би дошао до броја 40, додаје још два јуса (два носна самогласника), истичући да ови гласови нису српски него бугарски. То се види из завршног записа, где Константин за своје дело каже: „Писа се /по томе/ колико је слова 40... јер њих 40 набројасмо, будући да споменусмо и два бугарска". Број 40 Константин није случајно изабрао. Овај број симболише нешто свето, божанско: Господ Исус Христос постио је 40 дана у пустињи, где га је ђаво искушавао; ${ }^{8}$ на небо се узнео у 40 . дан по васкрсењу; после васкрсења 40 дана се јављао Апостолима, говорећи им о Царству божјем; ${ }^{9}$ васкршњи пост траје 40 дана итд.

Ово изузетно важно и значајно Константиново дело писано је веома сложеним, на многим местима тешко разумљивим језиком. Зато његово превођење и тумачење није нимало лако. То признаје и Ватрослав Јагић, који каже: „Без обзира на моју жељу да Константиново дело учиним разумљивим, због чега сам /уз/ њега дао тумачења, постоји бојазан да ће мало ко бити у стању да уђе у његову суштину, онако како је мени

${ }^{5}$ Нав. дело, стр. 135.

${ }^{6}$ К. Филозоф, Повест о словима; Житије деспота Стебана Лазаревића, Стара српска књижевност у 24 књиге, књ. 11, приредила проф. др Гордана Јовановић, Београд, 1989, стр. 10.

7 Нав. дело, стр. 16, 17.

8 Мт 4.1, 2; Библијске цитате дајем према: Свето писмо Старога и Новога завјета, превео Стари завјет Ђ. Даничић, Нови завјет превео Вук Стеф. Караџић, Британско и инострано Библијско друштво, Београд.

9 Л. Мирковић, Хеортологија или историјски развитак и богослужење празника православне источне иркве, Београд, 1961, стр. 223. 
успело после многих покушаја". ${ }^{10}$ Зато В. Јагић укратко препричава сваку од 40 глава, дајући основни садржај сваке од њих, а указује и на места која су и њему самом остала нејасна. По свој прилици из истих разлога и други наш научник, Ђуро Даничић, исто то чини - такође препричава и коментарише сваку од 40 глава. ${ }^{11}$

Сказаније о писменех је ортографско-графички трактат који је Константин написао после 1423. г., о чему постоје посредни докази. ${ }^{12}$ Намера Константинова била је да помогне српским писцима и преписивачима да правилно и лепо пишу и да им укаже на шта треба да обрате посебну пажњу; он први покушава да среди и нормира правопис српског језика; сматра да тадашњи писмени Срби, којима је посао да преводе и преписују богослужбене књиге, слабо знају грчки језик са кога се књиге преводе, а нису много вични ни српском правопису па због свега тога долази до „кварења светих књига”, а све то може водити настанку јереси и бити супротно „правом”, одн. православном учењу. Константин је, дакле, својом расправом, одн. трактатом, желео све то да спречи и да људима од пера помогне у писању, преписивању и превођењу. ${ }^{13}$

За своје излагање изабрала сам следеће главе: гл. 19 Како да учимо речи; гл. 20: Како да се учи /молитва/ „Цару небески”; гл. 21: Како да се учи /молитва/ „Свети Боже”; гл. 22: Слава Оиу и Сину...; гл. 23: Пресвета Тројице.

Изабрала сам ове главе због тога што Константин Филозоф у њима наступа и као богослов и као педагог. Треба свакако истаћи да је његово Сказаније нека врста и педагошког приручника за учитеље који српску децу треба да уче писмености. Зато им на многим местима даје и одговарајућа упутства и савете. С једне стране излаже како децу треба учити молитвама, а с друге - даје неопходна богословска објашњења, потребна не само деци, него и учитељу.

Наводимо део превода 19 главе: „Тако, опет, наредише Свети Оци, кад деца потпуно савладају слова, тада пре свега да им се напише $3 a$ мо-

10 В. Ягич, Разсуждения южнославянской и русской старины иерковно-славянском языкъ (Изслъдования по русскомуязыку, Том I), Санктпетербургъ, 18851895, стр. 488. Превод је рађен према издању Сказанија које је В. Јагић објавио у наведеном раду. У даљем тексту скраћеница ће бити Ј., стр...

11 Ђ. Даничић, Книга Константина Философа о правопису, Старине, књ. I, JАЗУ, у Загребу, 1869, стр. 2 и даље.

12 К. Филозоф, Повест о словима..., стр. 14.

13 Г. Јовановић, Деспот Стефан Лазаревић и Ресавска школа, Ресавска школа и деспот Стефан Лазаревић (округли сто, манастир Манасија, 28.8.1993), Дани српског духовног преображења, I, Деспотовац, 1994, стр. 73. 
литву Светих Отаца наших; немој помислити, учитељу, да је овај захтев безразложан. Зар га и у Правилу Светих Отаца нећеш наћи - тамо где су и цели законици са свим правилима?" 14

Шта су то „цели законици са свим правилима”? То је номоканон „тзв. српског (Савинског) типа", ${ }^{15}$ или законик, како је овај грчки термин писар Богдан у XIII веку превео на српски, а у каснијим преписима Савиног номоканона налазе се и преводи законоправило или правилозаконик који упућују на то да се „у оба случаја подразумева књига - зборник црквених правила и грађанских закона". ${ }^{16}$ Зашто Константин упућује баш на ове законике (одн. законик)? Зато што је потребно „да прво укажеш детету на правац којим /ако буде ишло/, клониће се свих јеретика и ићи тачно путем божанствених Отаца, као што су и они или за божанственим Апостолима, а Апостоли за Господом; да бисмо тако, наоружани овим крстоликим оружјем (Код Константина: крсним оружјем), тачно испуњавали Божје заповести, као што од Отаца научисмо; на тај ћемо начин, без сумње, савладати васколико ђавољи страх. Ова молитва је крстолико представљена (Код Константина: ову молитву показује крст) у Законоправилу у којем се налази и њено тумачење”. Овако изгледа у Константиновом Сказанију:

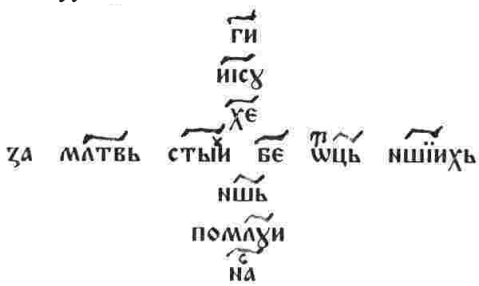

У тој краткој молитви, која је позната и као молитва ума „садржана је главнина православног учења хришћанског.".

${ }^{14}$ J., стр. 434.

15 J., стр. 434, нап. 1.

${ }_{16}$ М. Петровић, О Законоправилу или Номоканону Светога Саве, Београд, 1990, стр. 21, 28, 30.

17 М. Петровић, Омилена молитва Светога Саве, Свети Сава и догматика, Свети Сава, приредили: Крсто Миловановић, Димитрије Калезић, Београд, Народно дело, 1995, стр. 51. Обичан човек, лаик, молећи се Богу, не употребљава устаљене формуле које су резервисане за свештена лица, него изговара речи: Молитвама Светих Отаи, наших, Господе Исусе Христе, Боже наш, помилуј нас, чиме даје до знања да нема смелости да се сам од себе моли Богу, него „моли Христа да се смилује на њега молитвама светих отаца". В. о овоме: Л. Мирковић, Православна литургика или наука о богослужену православне источне иркве, Београд, 1965, стр. 195. 
нује и као крстолико оружје којим се, или помоћу кога се, испуњавају Божје заповести. Сматрам да је важно рећи да ни у једном досад познатом препису Номоканона светога Саве ова молитва није забележена у облику крста. ${ }^{18}$ Сигурно да је Константин имао неки препис Номоканона у коме је ова молитва заиста била у облику крста, али тај препис до нас није дошао. Утолико је Константиново сведочанство за нас драгоценије. И још је нешто важно и значајно. Наиме, ова молитва била је омиљена молитва Светога Саве па је њу, приликом састављања свога Законоправила, ставио „одмах после Слова о васељенским и помесним саборима, тј. у другој уводној глави". ${ }^{19}$ Свети Сава је, истовремено, дао и опширно богословско тумачење ове молитве. Константин чини исто - од свих молитава које деца треба да науче, она је на првом месту и прво њу треба да савладају. Нема сумње да се Константин Филозоф приклонио несумњивом ауторитету који је Свети Сава имао не само као црквени великодостојник, него и као врстан теолог. Придајући изузетан значај овој молитви, Константин је даје пуним речима, раздељеним на слогове, смештеним у четири реда:

z̧а. Мо. ми. Твь

све. Ты. и. $\chi^{\mathbf{b}}$. ш. ць. на. шї. и. $X^{\mathbf{b}}$.

го. спо. Аи. І. и. соу. хрї. сте.

во. же. на. шъ. กо. ми. nоу. и. Na. съ.

То значи да деца треба најпре да виде и читају молитву написану без скраћивања (без титлова): „И као што раније рекох, треба писати без титлова док [ученик] не уђе у суштину писања. То [може бити] и после [исписане] три или четири таблице.. ако се [прилежно учи], већ од пете таблице и учитељ и ученик осећаће се много сигурнији”. тин има на уму? Њему је веома стало до тога да дете треба најпре да научи „лепо писати, јер како му напишеш, тако ће се дете [и] навићи да пише”. ${ }^{21}$ Уз то додаје и изванредну мисао: „у основи [у темељу] све је садржано, [све се налази]". 22 Овај Константинов захтев одражава његову основну мисао, коју још једном понављам, а која се провлачи кроз чита-

18 За ово обавештење као и за многе драгоцене савете срдачно захваљујем г. др Миодрагу Петровићу, научном саветнику Историјског института САНУ.

19 М. Петровић, Омиљена молитва..., стр. 51.

20 J., стр. 436.

${ }^{21}$ J., стр. 437.

22 J., стр. 437. 
во његово дело - треба веома брижљиво и тачно преписивати и преводити богослужбене књиге и стално имати на уму „право учење”; ${ }^{23}$ треба се, каже он, непрестано борити против оних „који бране да се изађе на прави пут", 24 одн. борити се против јеретика. Све се то, према Константину, може постићи ако се држимо учења Светих Отаца и одлука седам васељенских сабора који су сигуран путоказ и ослонац. Наводим Константинове речи: „А ја вам кажем да кад је у кући оружје, страха нема”. 25 Све ово указује на то да је Константин морао знати за чувену Беседу Светога Саве о правој вери. ${ }^{26}$ Ево речи Светога Саве: „Стога вас, браћо и чеда, ово прво молим да, положивши сву наду своју на Бога, држимо се пре свега праве вере Његове. Јер, као што рече Апостол, „темеља другог нико не може поставити осим онога којега постави Дух Свети преко светих Апостола и богоносних Отаца, а то је - права вера која је на светих седам Васељенских Сабора потврђена и проповедана". ${ }^{27}$ А на завршетку своје Беседе Свети Сава каже: „И нека буду речи ове, које вам ја данас заповедам, написане на срцима вашим и у душама вашим, да се бојите Господа Бога Сведржитеља, и Њему једноме да служите са страхом и трепетом"... Да „држите заповести Његове, и да извршујете пред очима Његовим све речи које вам заповедих”, „да буде добро вама и синовима вашим после вас..." ${ }^{28}$ Пошто је у својој Беседи навео све оно чега треба да се држе, у шта треба да верују православни хришћани, за отпаднике од такве вере и таквог учења, одн. за јеретике и њихову јерес каже: „Ово је богољубиви [моји] догмат православних Отачких предања. Следујући њима, и ми тако верујемо и тако исповедамо, а све јеретике и сву јерес њихову проклињемо". 29

Све ово што се налази у Беседи Светога Саве, поново истичем, веома је присутно - и по духу и по суштини - у Константиновом делу. Уосталом, необично би било да Константин, живећи у близини деспота Сте-

\footnotetext{
23 J., стр. 437 и даље.

24 J., стр. 444.

25 J., стр. 444.
}

26 Ова Беседа може се прочитати у изванредном преводу владике захумско-херцеговачког господина Атанасија: Беседа Светога Саве о правој вери; Свети Сава, приредили: Крсто Миловановић, Димитрије Калезић, Београд, Народно дело, 1995, стр. 9-18. Уз превод су дати и изузетно драгоцени коментари и објашњења.

${ }_{27}$ Нав. дело, стр. 9.

${ }_{28}$ Нав. дело, стр. 18.

${ }^{29}$ Нав. дело, стр. 14. 
фана, кога је веома ценио и поштовао, не зна за дело једног од најславнијих и најзначајнијих Деспотових предака.

У 20. глави разматра се молитва Цару небески којом се призива Дух Свети. И кад је о овој молитви реч, Константин говори и као теолог и као педагог. Он, наиме, каже: „Треба знати да се и Цару небески деци не пише како следи у богослужењу, него и то по заповести Светих Отаца. На [тим заповестима] засновано је богослужење па [на њима мора бити засновано] и ово [поучавање деце]. Пошто су [научена] да буду смерна у покорности Светим Оцима, [деца] не треба много да мудрују, него да иду њиховим стопама. Треба да се помоле за долазак Утешитељев, а [кад то испуне, онда их] тако усмерити да ка бољем теже". ${ }^{30}$ И у овој глави Константин не пропушта да осуди јеретике за које каже да „бледословет"з1, одн. да 'неуверљиво говоре', додајући да то чине „ако не говорећи, а оно пишући и истину забрањују; сви они су осућени... јер су и Божанствени Оци осудили јеретичко учење". ${ }^{32}$ Следује молитва:

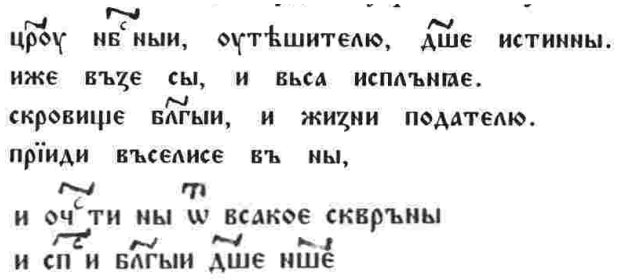

И завршава: „Ако по вољи буде Самодршцу (деспоту Стефану - Г. Ј.) и о овоме ћемо опширније говорити". ${ }^{33}$

Следећа, 21. глава, на неки је начин наставак 20. У претходној је разматрана молитва којом се призива Дух Свети, а у овој се налази молитва упућена Светој Тројици:

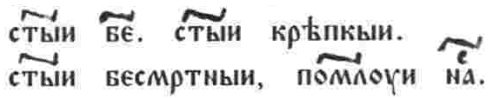

„И шта? Није ли, без сумње, пре свих молитава требало да се стави јеванђељска молитва коју је сам Господ заповедио? [Није], него је [дата на начин] којим ће [ти] се помоћи да се навикнеш на оно што [је твоја] звезда-водиља. [Дата је тако] како би [схватио] да нико ко није просветљен благодаћу Духа [Светога] није спреман за узвишено; [и] као што Господ

\footnotetext{
30 J., стр. 437.

31 J., стр. 437.

32 J., стр. 437.

33 J., стр. 438.
} 
рече: „ако се ко наново не роди, не може видјети царства Божијега.” [дата је тако како би се научио] да верујеш у јединога Бога оличеног у три лица; [да схватиш] како се најпре [уз помоћ] Сина приклања Оцу, а [уз помоћ] Духа [Светога] сви се дарови добијају према заслузи. Тај Дух све испуњава. Он и припроста срца учвршћује и доноси им утеху, чак и кад се нађу међу туђинима..." ${ }^{35}$ Даље следи прича за коју В. Јагић каже да није утврђено откуд она у Константиновом делу. ${ }^{36}$ Дајем њен превод: „Као што се за нашег времена догоди у Јерусалиму, дете [рођено] од мајке хришћанке и оца Сарацена сазнаде после мајчине смрти да је од ње просветљено даром Духа Светога па не хтеде да у време Свете Четрдесетнице (одн. ускршњег поста - Г. Ј.) узима храну; имаше [то дете], о чуда, [само] неколико година. А од честих напада те брзе звери (одн. глади Г. Ј.) и смрт беше спремно прихватити, али не одустаде од [поста], него узвикну: „хришћанин сам!” Од тада сви хришћани [у то време] данас посте".37

„И као што рекосмо, кад све ово прихватиш, онда, будући спреман, приступи страшној молитви, јер та молитва није за савршене [људе]; каже Онај који ју је заповедио": Уђи у одаје своје - а то је твоје унутрашње биће - затвори врата своје телесне љуштуре па се у тишини, са страхом, помоли; ${ }^{38}$ и да знаш како се и коме се молиш". Наставља се даље Константинов коментар: „Њу (одн. ову молитву - Г. Ј.) нису [изговорила] уста Светих Отаца, него [уста] анђеоска". Следи прича којом се ово потврђује: „Кад је ученик Јована Златоустог, мислим да је то био Прокл ${ }^{39}$, будући на патријаршиском трону у Цариграду, приредио литију, сви присутни били су одушевљени једним дететом које је, као да је бестелесно, лебдело у ваздуху. И пошто као да је сишло с небеса, исприча присутнима да тамо [на небесима] не поју као ми „Свети [Боже], распни се!”, него „Свети, бесмртни, помилуј нас!".

У наставку се даје богословско тумачење сваког појединачног дела ове молитве: „Свети Боже говори о Оцу, изворишту исконског ума... [а] откуда ово? Отуда што је код Мојсија, великог међу пророцима, нађено [оно] што говори сам Господ; да начинимо човјека по својем обличју,

34 J., стр. 438; Jo 3.3.

35 J., стр. 438. Могуће је да Константин овде мисли на себе, јер је у Србији туђинац.

36 J., стр. 438, нап. 2.

37 J., стр. 438.

38 Мт 6.1: Пазите да правду своју не чините пред људима да вас они виде; иначе плате немате од оца својега који је на небесима.

39 J., стр. 439, нап. 2. 
као што смо ми"; ${ }^{40}$ што ће рећи: Ум, Логос и Дух...; ${ }^{41}$ Свети крепки јесте реч беспочетна, силна према Давиду: „Ријечју Господњом небеса се створише....2; Свети бесмртни [значи] да Дух Господњи све оживљава и све спаја; и о [овоме] се према Давиду може рећи": духом уста његовијех сва војска његова. ${ }^{43}$ Коментаришући устаљену фразу помилуј нас изричито каже да је реч „о једином Богу у три лица” (Отац, Син и Дух Свети - Г. Ј.), па сагласно томе „... пази да не кажеш помилујте нас, него помилуј нас, jep је [реч] о једном божанству". 4

У краткој 22. глави налази се слављење Свете Тројице Слава Оиу и Сину и Светоме Духу; ${ }^{45}$ каже Константин: „једну славу треба узносити једином Богу; а пошто је [свештеник], благословивши, [то] изрекао и помолио се, достојан је да и Бога слави; испросивши на тај начин милост и прославивши Бога, моли се за опроштај грехова".

Глава 23 посвећена је молитви Пресветој Тројици:

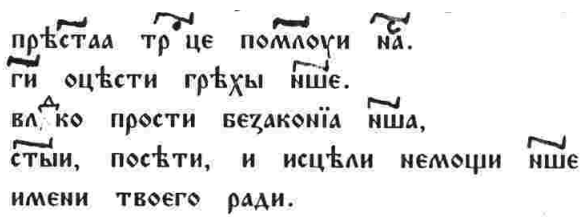

Следује тумачење и ове молитве: „... Господе, очисти грехе наше значи да смо Теби, исконској светлости, згрешили, да смо ум изопачили који је према Твоме обличју, Владико, опрости безакоюа наша [односи се] на Реч Божију која је владар над свим; и као што рече Отац: 'отац не суди никоме, него сав суд даде сину'” 46 Ти који си сишао с небеса и „ушавши у утробу Пречисте Дјеве... уподоби се нама у свему осим греха"; ${ }^{47}$ и нас не-

\footnotetext{
${ }^{40}$ I Mojc. 1.26.

${ }^{41}$ J., стр. 439.

42 Пс. 33.6.

${ }^{43}$ Пс. 33.6.

${ }^{44}$ J., стр. 440.

45 J., стр. 440.

${ }^{46}$ Jo 5.22 .
}

47 Мислим да у објашњавању реченице Владико, опрости безакоња наша Константин има пред очима Беседу о правој вери Светога Саве. Реченица: „... и ушавши у утробу Пречисте Дјеве... уподоби се нама у свему осим греха" преузета је из 5. главе Беседе (Беседа Светога Саве.., стр. 11). Верујемо да би теолози, детаљним поређењем Учень о правој вери и Сказанија о писменех, нашли и више доказа о непосредном утицају овог списа Светога Саве на Константина. Мој је утисак, читајући оба дела, да је он несумњив. 
достојне удостојио си вазнесењем у небески живот; ми не само што смо Оцу Твоме згрешили, него смо и после толике благодати зло чинили... чинити зло још је већи грех; али ти, истинити Свети Душе, кад се од зла очистимо, прими то, посети нас и исцели немоћи наше и просветли нас имена Твојега ради, како не бисмо греху служили, него име Твоје прослављали; кад нас Ти посетиш, све ће мане бити исправљене..." 48

На крају објашњава реч амин: „... та је [реч] заповедна за људе, према Богу је молбена и значи нека тако буде". ${ }^{4}$

Као закључак рекла бих следеће: Сказаније о писменех веома је важан извор за изучавање наше прошлости. У њему ће наћи много драгоцених података и лингвисти и теолози и педагози и историчари. Стога оно заслужује пуну научну пажњу.

Gordana Jovanović

"HOLY WRIT" AS A MOTIF AND THE BIBLICAL PASSAGES IN "SKAZANIE O PISMENEH" BY CONSTANTIN THE PHILOSOPHER

\section{Summary}

Constantin The Philosopher, a learned and educated Bulgarian, spent a part of his life in Serbia where he came between 1410 and 1413. We have some indirect proofs about his dwelling at the court of a despot Stephan Lazarevich in Belgrade.

His book Skazanie o pismeneh is an ortographic-graphic tractate which among other things contains the instructions for the Serbian writers and copy how they should write properly and where particularly to pay attention. His book has 40 chapters and this study deals with the ones in which Constantin as a pedagogist explains the teachers how to teach the most important Christian prayers to the Serbian children.

\footnotetext{
48 J., стр. 440-441.

49 J., стр. 441.
} 